Dr DRAGIŠA D. VASIĆ, vanredni profesor

Univerzitet u Banjoj Luci, Filozofski fakultet

Banja Luka, Republika Srpska, Bosna i Hercegovina

dragisa.vasic@ff.unibl.org

pregledni $\mathrm{rad} /$ review article

UDK 930:316.75(497.6 ФБиХ)"1995/..."

primljeno / received: 2. 8. 2020.

37.091.64::93/94(497.6 ФБиХ)"1995/..."

prihvaćeno / accepted: 20. 11. 2020.

https://doi.org/10.29362/ist20veka.2021.1.vas.215-232

\title{
SAVREMENA NACIONALNA ISTORIJA U BOŠNJAČKIM UDŽBENICIMA ZA OSNOVNU I SREDNJE ŠKOLE
}

APSTRAKT: Udžbenici istorije u bošnjačkom obrazovnom sistemu u Bosni i Hercegovini praćeni su kritikama koje se uveliko razlikuju po polazištima, metodologiji i zaključcima. U ovom članku se razrješava dilema o bošnjačkom ili bosanskohercegovačkom karakteru sadržaja savremene nacionalne istorije u važećim udžbenicima i njihovoj dopuni za osnovnu i srednje škole. Takođe, u njima se uočavaju i razmatraju glavni motiv i suštinske odlike (pseudonaučna, viktimološka i srbofobična) interpretacije zbivanja, pojava i procesa 20. vijeka.

KLJUČNE RIJEČI: Bosna i Hercegovina, Bošnjaci, udžbenici, viktimizacija, srbofobija, pseudoistorija

\section{Istorija, povijest i historija}

Propast Socijalističke Federativne Republike Jugoslavije najteže je pogodila njenu centralnu republiku - Bosnu i Hercegovinu $(\mathrm{BiH})$. U razornom građanskom ratu 1992-1995. godine podijeljen je, između ostalog, i njen obrazovni sistem na: muslimanski/bošnjački, hrvatski i srpski. Ta podjela je de facto očuvana i nakon Dejtonskog mira u državi dva entiteta i tri naroda, mada su iz bošnjačke sredine i uticajnih inostranih centara političke moći zagovarane ideje i vođene aktivnosti u cilju unitarizacije $\mathrm{BiH} .{ }^{1}$

\footnotetext{
${ }^{1}$ Haike Kargo i Katarina Batarilo, Reforma nastave historije u Bosni i Hercegovini. Modernizacija udžbenika historije u BiH: od uklanjanja uvredljivog sadržaja iz udžbenika u toku 1999. godine do nove generacije udžbenika u školskoj 2007./2008. godini (Braunschweig: Institut za međunarodno istraživanje udžbenika Georg Eckert, 2008); Falk Pingel, "A Clash of Communication? Intervening in Textbook Writing and Curriculum Development in Bosnia and Herzegovina after the War 1992-1995", in: History Education and Conflict Transformation. Social Psychological Theories, History Teaching and Reconciliation, ed. Charis Psaltis, Mario Carretero and Sabina Čehajić-Clancy (Palgrave Macmillan, 2017), 231-254; Драгиша Д. Васић, „Научна
} 
Razlike između tri obrazovna sistema u BiH najuočljivije su u nastavnim programima i udžbenicima tzv. nacionalne grupe predmeta: maternji jezik, istorija, geografija, vjeronauka. Očigledne su i u nazivima tih predmeta, pa se tako imenuju srpski, hrvatski i bosanski jezik, te istorija, povijest i historija. ${ }^{2} \mathrm{U}$ obrazovnom sistemu Republike Srpske nastava istorije uglavnom se izvodi na srpskom jeziku i za polazište ima srpski narod. Povijest je predmet u onim školama kantonâ Federacije BiH u kojima se nastava izvodi na hrvatskom jeziku. U tom obrazovnom sistemu nastavni programi i udžbenici uglavnom su preuzeti iz Hrvatske uz neznatna prilagođavanja prilikama u BiH. Historija se uči na „bosanskom“ jeziku u školama kantonâ u Federaciji BiH i dvadesetak škola u Srpskoj u kojima su Bošnjaci većina. Naime, u vrijeme propasti Jugoslavije vođstvo Muslimana je srpskohrvatski/hrvatsko-srpski jezik, kako se do tada zvanično zvao, preimenovalo u bosanski, nacionalno ime u Bošnjak, a istoriju u historiju. Novi nazivi naroda i, naročito, jezika se na dvije stranice bosanskohercegovačkog trougla uglavnom prepoznaju kao uzurpacija imena zajedničke domovine u cilju njene unitarizacije.

Udžbenici su posvuda čest predmet kritike. O kontroverznim i osjetljivim temama iz nacionalne prošlosti (Drugi svjetski rat, zbivanja 1990-ih godina) u njima brojni su površni, ispolitizovani i ostrašćeni prilozi u mas-medijima, ali i kritike koje, bar formalno, pretenduju na stručni i naučni nivo. U bošnjačkoj sredini, kao i u inostranstvu, srpski i hrvatski nastavni programi i udžbenici tzv. nacionalne grupe predmeta u BiH obično se ozloglašavaju ,etnocentričnim“ i sredstvima nacionalističke i separatističke politike. Istovremeno, ocjene udžbenika historije su raznovrsne. Po jednima, samo oni nisu „etnocentrični““; po drugima, najmanje su loši; ${ }^{4}$ po trećima, podjednako su loši kao i srpski i

заснованост наставе историје у основним и средњим школама у Републици Српској“, у: Настава историје у Републичи Српској - стање и перспективе, ур. Драго Бранковић (Бања Лука: Академија наука и умјетности Републике Српске, 2019), 22-30.

2 Radi ekonomičnosti u izlaganju, dalje u ovom radu kada je riječ o nastavnim programima i udžbenicima kod Hrvata koristi se pojam povijest, a kod Bošnjaka pojam historija.

${ }^{3}$ Mensur Husić, „Ideološka dimenzija obrazovanja u Bosni i Hercegovini - paradigma koja se obnavlja“, Zbornik radova Pravnog fakulteta u Tuzli, god. III, br. 2, (2017), 162-176; Jasna Jozelić, "Teaching History with an Ethno-Nacionalistic Approach: History Textbooks in educaton System of Bosnia and Herzegovina", in: Nationhood and Politicization of History in School Textbooks. Identity, the Curriculum and Educational Media, ed. Gorana Ognjenović and Jasna Jozelić (Palgrave Macmillan, 2020), 213-225.

${ }^{4}$ H. Kargo i K. Batarilo, $n$. d.; Emir Filipović, Sanja Gladanac, Amila Kasumović, Marija Naletilić, Mirjana Trbojević i Edin Veladžić, Zloupotreba istorije u procesima koji su doveli do zadnjeg rata u Bosni i Hercegovini: Okvir za promjenu paradigme u izučavanju istorije u BiH školama, ur. Edin Radušić (Sarajevo: Udruženje nastavnika i profesora historije/istorije/povijesti u Bosne i Hercegovine - EUROCLIO HIP BIH, 2015); Melisa Forić Plasto, „Podijeljena prošlost za podijeljenu budućnost!? Rat 1992-1995. u aktuelnim bosanskohercegovačkim udžbenicima historije“, Radovi Filozofskog fakulteta u Sarajevu (Historija, Historija umjetnosti, Arheologija), knj. 6, (2019), 247-248; „Ratovi u udžbenicima. Analiza sadržaja o ratovima 90-ih u udžbenicima historije u Bosni i Hercegovini, Hrvatskoj i Srbiji“, pripremila Melisa Forić Plasto, http://cliohipbih.ba/wp-content/uploads/2018/12/Ratovi-u-ud\%C5\%BEbenicima.pdf (pristupljeno 20. 11. 2019). Bošnjačka nacionalna ideologija i politika najnegativniji odnos ima prema Srpskoj i Srbiji, potom Hrvatima u BiH i Hrvatskoj. Upravo tako je M. Forić Plasto vrednovala sadržaje udžbenikâ. Ali, u njenoj analizi postoji izuzetak: višu ocjenu i u odnosu na bošnjačku 
hrvatski; ${ }^{5}$ a objavljena je i kritika sa zaključkom da su isti sredstvo indoktrinacije mladih naraštaja u cilju formiranja svijesti o ,viševjekovnom kontinuitetu državnosti Bosne i Hercegovine, čiji su oni (,Bošnjaci‘) nosioci“, kao i svijesti o „Srbima kao genocidnom narodu i najgorim muslimanskim neprijateljima“. 6

Srbofobija je pojava uočena i u udžbenicima istorije u Hrvatskoj, Crnoj Gori i na Kosovu. ${ }^{7}$ Njeno ishodište je uglavnom u nacionalizmima čija je bitna odlika suprotstavljenost Srbiji i Srbima, koji su u udžbeničkoj literaturi, u svrhu učvršćivanja i razvijanja nacionalnog identiteta, predstavljeni kao istorijski neprijatelji. Srbofobija u hrvatskim, crnogorskim i albanskim udžbenicima uporediva je sa rusofobijom u udžbenicima istorije država u susjedstvu Rusije (Ukrajina, Gruzija, Uzbekistan, Litvanija, Letonija, Estonija, Poljska). ${ }^{8}$

Inače, udžbenik je, pored nastavnika, osnovni izvor znanja za učenike. Takođe, osnovno je nastavno sredstvo. Piše se na osnovu nastavnog programa za određeni razred, a odobravaju ga nosioci obrazovne politike. Udžbenici istorije obuhvataju sažete i uzrastu i predznanjima učenika prilagođene rezultate naučne istoriografije. Oni su mjerilo zrelosti jedne istoriografije, ali i ogledalo opšteg stanja određenog društva. ${ }^{9}$

Na spisku odobrenih udžbenika Federalnog ministarstva obrazovanja i nauke za školsku 2020/2021. godinu ${ }^{10}$ sadržaji savremene historije zastupljeni

udžbeničku literaturu dala je udžbeniku Snježane Koren, profesorice metodike nastave istorije iz Zagreba. Kako su udžbenici manje ili više odraz zvanične politike prošlosti, sadržaji o BiH i u tom hrvatskom udžbeniku svakako nisu u skladu sa bošnjačkom nacionalnom ideologijom i politikom. U objašnjenju paradoksa u kritici sarajevske metodičarke treba imati u vidu činjenicu da je ona doktorand na Odsjeku za povijest Filozofskog fakulteta Sveučilišta u Zagrebu.

${ }^{5}$ Vera Katz, „Analiza udžbenika historije u Bosni i Hercegovini (8. i 9. razred osnovne škole, 4. razred gimnazije i 1. i 2. razred stručnih škola)“, u: Udžbenici istorije u post-konfliktnim društvima: Obrazovanje za pomirenje?, ur. Marijana Toma (Beograd: Fond za humanitarno pravo, 2015), 5263; Obrazovanje u BiH: čemu (ne) učimo djecu? Analiza sadržaja nacionalne grupe predmeta u osnovnim školama (Sarajevo: Mas Media Sarajevo, Fond otvoreno društvo BiH, 2017).

${ }^{6}$ Горан Латиновић, „О муслиманским уџбеницима историје“, Зборник за историју Босне и Хериеговине, 6, (2009), 329-343.

7 Vidjeti: Александар Стаматовић, Антисрпство у уцбеницима историје у Црној Гори (Подгорица: Српско народно вијеће, 2007); Domagoj Švigir, „Slika, drugoga‘: predodžbe o Srbima u hrvatskim udžbenicima povijesti za osnovnu školu od 1990. do 2012. godine“, Historijski zbornik, god. LXXI, br. 1, (2018), 105-134; Божица Славковић Мирић, „Српскоалбански односи у албанском уџбенику за осми разред основне школе“, Токови историје, бр. 1, (2020), 199-220.

${ }^{8}$ Освещение общей истории России и народов постсоветских стран в школьных учебниках истории новых независимых государств, ред. А. А. Данилов и А. И. Вдовин (Москва: Государственый клуб, Национальная лаборатория внешней политики, 2009); В. Э. Багдасарян, „Становление образа исторического врага в школьных учебниках истории на постсоветском пространстве“, в: Преподование военной истории в Роосии и за рубежсм, ред. К. А. Пахалюка (Москва, Санкт-Петербург: Нестор-История, 2018), 67-86.

${ }^{9}$ Falk Pingel, UNESCO. Vodič za istraživanje i reviziju udžbenika (Zagreb: Profil, 2000); Иван Ивић, Ана Пешикан и Слободанка Антић, Водич за добар уцбеник. Општи стандарди квалитета уибеника (Нови Сад: Платонеум, 2010).

10 „Spisak odobrenih radnih udžbenika, priručnika, radnih listova i zbirki zadataka za osnovne škole, gimnazije i srednje tehničke i stručne škole za školsku 2020/2021. godinu“, Federalno ministarstvo obrazovanja i nauke, http://www.fmon.gov.ba/Upload/Ostalo/5bfc2420-9e9b- 
su u udžbeniku za deveti razred osnovne škole (autori Izet Šabotić i Mirza Čehajić), ${ }^{11}$ kao i u dva udžbenika za četvrti razred gimnazije (autori Zijad Šehić, Aida Kovačević i Alma Leka, ${ }^{12}$ te Hadžija Hadžiabdić, Edis Dervišagić, Alen Mulić i Vahidin Mehić ${ }^{13}$ ); posljednji autorski tim je potpisan i u udžbeniku za srednje tehničke i stručne škole. ${ }^{14}$ Od kraja školske 2017/2018. godine u Kantonu Sarajevo, a potom i u više drugih kantona, koristi se dopuna za udžbenike historije u osnovnim i srednjim školama, naslovljena Nastavni materijal za izučavanje opsade Sarajeva i zločina genocida počinjenog u Bosni i Hercegovini u periodu od 1992. do 1995. godine u osnovnim i srednjim školama Kantona Sarajevo (dalje: Nastavni materijal, autori Azerina Muminović, Asmir Hasičić i Melisa Forić Plasto). ${ }^{15}$

Više knjiga koje se nalaze u bibliografijama navedenih udžbenika kritičari smještaju izvan granica nauke. Tako se u bibliografiji udžbenika za srednje tehničke i stručne škole nalaze knjige: Safvetbeg Bašagić, Kratka uputa u prošlost Bosne (Sarajevo, 1900); Noel Malkolm, Povijest Bosne (Zagreb - Sarajevo, 1995); Enver Imamović, Porijeklo i pripadnost stanovništva Bosne i Hercegovine (Sarajevo, 1998); Mustafa Imamović, Historija Bošnjaka (Sarajevo, 1998). ${ }^{16}$ Sinteza M. Imamovića, za koju je sam autor priznao da je mitologija, ${ }^{17}$

4208-9a6d-e24c93096b42_Spisak\%20odobrenih\%20udzbenika\%20za\%202020-2021.\%20 godina.pdf (pristupljeno 19.6. 2020).

${ }^{11}$ Izet Šabotić i Mirza Čehajić, Historija. Udžbenik za deveti razred devetogodišnje osnovne škole (Tuzla: NAM, Zenica: Vrijeme, 2012).

${ }^{12}$ Zijad Šehić, Aida Kovačević i Alma Leka, Historija, istorija, povijest: udžbenik sa čitankom za četvrti razred gimnazije (Sarajevo: Sarajevo Publishing, 2007).

${ }^{13}$ Hadžija Hadžiabdić i dr., Historija/Istorija/Povijest 4, udžbenik za četvrti razred gimnazije (Tuzla: Bosanska knjiga, 2007).

${ }^{14}$ Hadžija Hadžiabdić i dr., Historija, udžbenik za srednje tehničke i stručne škole (Tuzla: Bosanska knjiga, 2007).

${ }^{15}$ A. Muminović, A. Hasičić i M. Forić Plasto, Nastavni materijal za izučavanje opsade Sarajeva $i$ zločina genocida počinjenog u Bosni i Hercegovini u periodu od 1992. do 1995. godine u osnovnim i srednjim školama Kantona Sarajevo (Sarajevo: Ministarstvo za obrazovanje, nauku i mlade Kantona Sarajevo, 2018). Skupština Kantona Sarajevo je juna 2017. donijela zakone o osnovnom i srednjem obrazovanju koji sadrže identične članove: „Ministar će osigurati da nastavni sadržaji, odnosno tematske jedinice koje su posvećene izučavanju zločina genocida počinjenog u Bosni i Hercegovini, u vremenskom periodu 1992-1995. godine, tematske jedinice posvećene opsadi Sarajeva, prema presudama nadležnih sudova, budu sastavni obavezujući dio nastavnog plana i programa." Potom je kantonalno Ministarstvo za obrazovanje, nauku i mlade formiralo stručnu komisiju koja je početkom 2018. godine završila izradu: nastavnih materijala namijenjenih učenicima (autori Azerima Muminović i Asmir Hasičić), metodičkog priručnika za nastavnike (autor Melisa Forić Plasto) i dodatnih nastavnih materijala za nastavnike (autori Zijad Šehić, Mesud Šadinlija i Jasmin Medić). Na kraju su usvojene izmjene nastavnih programa savremene historije u kojima je izučavanje stradanja Muslimana/Bošnjaka u ratu 1992-1995. godine dobilo prioritet. Opširnije u: Драгиша Д. Васић, „Настава хисторије или настава виктимологије и србофобије? О изучавању рата 1992-1995. године у школама Кантона Сарајево“, Српски историјски часопис, II, (2020), 141-178.

${ }^{16}$ Neki od kritičkih osvrta na ove knjige u: Milorad Ekmecic, ",Shorter History" (Noel Malcolm, Bosnia. A Short History. Macmillan, London 1994, pp 332)”, Dialogue, 15, (1995); Enver Redžić, Sto godina muslimanske politike u tezama i kontroverzama istorijske nauke. Geneza ideje bosanske, bošnjačke nacije (Sarajevo: ANUBiH, Institut za istoriju u Sarajevu, 2000); Srećko M. Džaja, 
nalazi se i u bibliografiji udžbenika za deveti razred. Malkolmova knjiga, objavljena na Zapadu tokom rata $\mathrm{u}$ BiH u funkciji bošnjačke politike, nalazi se u bibliografijama svih pomenutih udžbenika.

Šta je istina o sadržaju udžbenika savremene historije u bošnjačkom obrazovnom sistemu? Da li su naučno zasnovani? Da li su i u kojoj mjeri srbofobični? Na početku: da li su bosanskohercegovački ili su, pak, ,etnocentrični““ tj. bošnjački?

\section{Historija/istorija/povijest Bosne i Hercegovine ili historija muslimana/Muslimana/Bošnjaka?}

Bošnjačka imena svih 12 autora udžbenikâ historije i njihove dopune upućuju na drugi dio dileme u podnaslovu. Ali, u predgovorima/uvodima udžbenikâ autori tvrde da obrađuju teme: „nacionalne historije“, „,naše domovine“, „bosanskohercegovačku historiju“. ${ }^{18}$ Naslove nastavnih tema nacionalne prošlosti odreda počinju sa $\mathrm{BiH}$ (npr. „Bosna i Hercegovina u vrijeme šestojanuarske diktature“, „Bosna i Hercegovina u Drugom svjetskom ratu“). U naslovima gimnazijskih udžbenika su i historija i istorija i povijest.

Jednostavnom i očiglednom rješenju dileme o bošnjačkom ili bosanskohercegovačkom karakteru udžbenikâ historije vodi analiza zastupljenosti ličnosti u njima. ${ }^{19} \mathrm{Na}$ četvrtoj stranici udžbenika za deveti razred osnovne škole data je lenta vremena na kojoj su predstavljeni najvažnija zbivanja i ličnosti savremenog doba. Nacionalna historija je na njoj ilustrovana fotografijama Mehmeda Spahe, Džemala Bijedića i Alije Izetbegovića (sa Tuđmanom i Miloševićem). U istom udžbeniku predstavljene su fotografijama i drugim ilustracijama ukupno 22 ličnosti iz Bosne i Hercegovine 20. vijeka, od kojih 13 nose muslimanska imena, ${ }^{20}$ pet katolička/hrvatska, ${ }^{21}$ a na tri ili četiri trebali su biti Srbi. $^{22}$ Većina nemuslimana birana je na osnovu podobnosti bošnjačkoj nacio-

„Tri kulturno-političke sastavnice Bosne i Hercegovine i moderna historiografija“, Forum Bosne: kultura-znanost-društvo-politika, 18/02, (2002); Zoran Milutinović, Bitka za prošlost. Ivo Andrić $i$ bošnjački nacionalizam (Beograd: Geopoetika izdavaštvo, 2018); Драгиша Д. Васић, „Историја и национални идентитет у сарајевској магли: примјери политизације и митологизације бошњачког историјског наратива“, Токови историје, бр. 2, (2020), 220-225.

${ }^{17}$ Mustafa Imamović, „Šta hoće SDA: ummu muslimana ili modernu državu?!“, Dani, 195, Sarajevo, 2. 3. 2001.

${ }^{18}$ I. Šabotić i M. Čehajić, Predgovor u n. d., 3; H. Hadžiabdić i dr., Predgovor u Historija, udžbenik za srednje tehničke $i$ stručne škole, 5; H. Hadžiabdić i dr., Predgovor u Historija/Istorija/Povijest 4, 5; Z. Šehić, A. Kovačević i A. Leka, Uvod u n. d., 4.

${ }^{19} \mathrm{U}$ analizi nisu uzeta u obzir suvoparna nabrajanja ličnosti kulturne istorije.

${ }^{20}$ Mustafa Golubić, Džemaludin efendija Čaušević, Elez Dervišević, Mehmed Spaho (dva puta), Džafer-beg Kulenović, Huska Miljković, Avdo Humo, Husein Husaga Čišić, Alija Sirotanović (dva puta), Džemal Bijedić (dva puta), Hamdija Pozderac, Ismet Mujezinović i Alija Izetbegović (na četiri fotografije).

${ }^{21}$ Ivan Merc, Stjepan Sarkotić, Gabrijel Jurkić, Adela Ber i Branko Mikulić.

$22 \mathrm{Na}$ fotografijama su Gavrilo Princip, Gojkomir Glogovac, Rodoljub Čolaković i Đuro Pucar Stari. G. Glogovac je rođen u Bileći, ali nije najjasnija njegova nacionalna pripadnost. R. Čolaković i Đ. Pucar Stari su na zajedničkoj fotografiji sa A. Humom. U udžbeniku na str. 26. postavljena je fo- 
nalnoj ideologiji. Tako se Gojkomir Glogovac istakao u borbi protiv vojske Srbije u Prvom svjetskom ratu, Rodoljub Čolaković i Đuro Pucar Stari doprinijeli su konstituisanju $\mathrm{BiH}$ kao republike socijalističke Jugoslavije, dok je Branko Mikulić zaslužan za inaugurisanje nacije Muslimani i osamostaljivanje BiH u Titovoj Jugoslaviji. ${ }^{23}$

U tekstu istog udžbenika pozitivno vrednovane ličnosti uglavnom su muslimani/Muslimani/Bošnjaci: reis-ul-ulema Islamske zajednice Džemaludin efendija Čaušević; Mehmed Spaho, vođa Jugoslovenske muslimanske organizacije (JMO); Huska Miljković, komandant muslimanske milicije u Cazinskoj Krajini u Drugom svjetskom ratu; Husein Husaga Čišić, ,prvi političar u socijalističkoj Jugoslaviji koji je otvorio pitanje položaja Bošnjaka“; Alija Sirotanović, ,proslavljeni bosanskohercegovački i jugoslovenski rudar"; komunistički rukovodioci Avdo Humo, Džemal Bijedić i Hamdija Pozderac (,zbog montirane afere i pritiska srbijanskih novina, bio je primoran podnijeti ostavku“); i Alija Izetbegović, vođa Muslimana/Bošnjaka na kraju 20. vijeka. Pozitivno vrednovan Hrvat iz BiH, pored Branka Mikulića, jeste fra Josip Markušić, zbog protivljenja podjeli Bosne i Hercegovine 1939. godine. Pozitivno vrednovan Srbin iz BiH, pored G. Glogovca i R. Čolakovića, jeste Vojislav Kecmanović, predsjednik Zemaljskog antifašističkog vijeća narodnog oslobođenja Bosne i Hercegovine. ${ }^{24}$

Na stranice udžbenika za srednje tehničke i stručne škole i udžbenika za četvrti razred gimnazije H. Hadžiabdić i drugi autori uvrstili su fotografije po pet muslimana/Muslimana/Bošnjaka, jednog Hrvata i jednog Srbina. ${ }^{25}$ Napisali su kratke biografije isključivo pripadnika vlastitog naroda. Tako za Mehmeda Spahu konstatuju u udžbeniku za srednje tehničke i stručne škole da je bio ,vođa bh. Muslimana“", ${ }^{26}$ dok u gimnazijskom udžbeniku pišu da je bio ,vođa bh. muslimana/Bošnjaka“. ${ }^{27}$ Za reisa Dž. Čauševića pišu u oba udžbenika: „da je bio neosporni duhovni vođa bh. Muslimana“ i ,da je dao veliki doprinos u vjerskom, kulturnom i političkom životu Bosne i Hercegovine u prvoj polovini 20.

tografija sa opisom „Policija odvodi atentatora Gavrila Principa“. Vladimir Dedijer u najstudioznijoj monografiji Sarajevskog atentata opisuje istu fotografiju: „Ferdinanda Bera, Pirncipovog poznanika, odvode u zatvor posle atentata“. Zabunu sa fotografijom razjasnio je na strani 423. pozivajući se na tekst samog F. Bera. Vladimir Dedijer, Sarajevski atentat, I-II, Reprint drugog dopunjenog izdanja (Banja Luka: Narodna i univerzitetska biblioteka, 2015).

${ }^{23}$ I. Šabotić i M. Čehajić, $n$. d., 126, 164, 176.

${ }^{24}$ Isto, 125, 136, 155, 163-164, 167, 175, 180.

${ }^{25} \mathrm{Za}$ razliku od gimnazijskog udžbenika, Ferdinand Ber je predstavljen kao Gavrilo Princip. Na ostalim portretima su: Mehmed Spaho, Džemaludin efendija Čaušević, Hasan Kikić, Alija Izetbegović i Ante Pavelić. U gimnazijskom udžbeniku nalazi se i portret Fadila Jahića Španca, dok je u udžbeniku za srednje tehničke i stručne škole portret Meše Selimovića.

${ }^{26}$ H. Hadžiabdić i dr., Historija, udžbenik za srednje tehničke i stručne škole, 327.

${ }^{27}$ H. Hadžiabdić i dr., Historija/Istorija/Povijest 4, 99. Etnonim Musliman upotrebljavao se od kraja sedme i početka osme decenije 20. vijeka. Zamijenjen je etnonimom Bošnjak 1993. godine odlukom Drugog bošnjačkog sabora. Z. Šehić, A. Kovačević i A. Leka u svom udžbeniku koriste ime Musliman i prije 1960-ih godina, što je anahronizam. Za razliku od njih, I. Šabotić i M. Čehajić upotrebljavaju anahrono u cijelom udžbeniku etnonim Bošnjak. O konfuziji nastaloj zbog toga pisali su: E. Kurtović, „U potrazi za boljom prošlošću“, http://www.skolegijum. ba/tekst/index/166 (pristupljeno 29. 4. 2017); Obrazovanje u BiH..., 133-134. 
stoljeća“. ${ }^{28}$ Hasan Kikić, za H. Hadžiabdića i dr., „predstavlja najizvorniju i umjetnički najsnažniju pojavu među bh. piscima međuratnog perioda“. ${ }^{29} \mathrm{U}$ gimnazijskom udžbeniku predstavili su i komunistu i antifašističkog borca Fadila Jahića Španca. ${ }^{30}$ Pored navedenih ličnosti, iz BiH je još u pozitivnom kontekstu pomenut V. Kecmanović. ${ }^{31}$

Z. Šehić, A. Kovačević i A. Leka od istorijskih ličnosti savremenog doba iz BiH navode samo G. Glogovca, M. Spahu i Dž. Kulenovića. Gradivo o Prvom svjetskom ratu ilustrovali su fotografijom koja je pogrešno opisana kao hapšenje G. Principa i portretom G. Glogovca. Kasnije periode ilustrovali su u udžbeniku svega jednim portretom ličnosti iz BiH - Ive Andrića.

U krugovima političke moći koji vode bošnjački narod od 1990. godine do danas uglavnom vlada negativan odnos prema načinu na koji je nobelovac Ivo Andrić u svojim djelima predstavio $\mathrm{BiH}$, a posebno muslimane. ${ }^{32}$ To se odrazilo i na sadržaje udžbenikâ historije. U udžbeniku za osnovce u nabrajanju književnika iz BiH između dva svjetska rata I. Andrić je na 12 . mjestu, ${ }^{33}$ a u socijalističkom periodu na trećem mjestu. ${ }^{34}$ Nema pomena Nobelove nagrade koju je dobio Andrić ni u gimnazijskom udžbeniku autora Z. Šehića, A. Kovačević i A. Leke. U pasusu tog udžbenika o prosvjeti i kulturi u BiH od 1918. do 1941. godine Andrić je na četvrtom mjestu. ${ }^{35} \mathrm{H}$. Hadžiabdić i dr. u svojim udžbenicima Andrića su u nabrajanju književnika iz BiH stavili na sedmo mjesto. ${ }^{36} \mathrm{U}$ njihovom udžbeniku za srednje tehničke i stručne škole Andrić je, pored portreta Meše Selimovića, na prvom mjestu u navođenju književnika iz socijalističkog perioda uz informaciju o dobijanju Nobelove nagrade. ${ }^{37}$

Z. Šehić, A. Kovačević i A. Leka napisali su opširan pasus o istoriji filma u socijalističkoj BiH navodeći 11 stvaralaca $\mathrm{i}$ šest njihovih ostvarenja, te istakli zapaženost domaćeg filma u inostranstvu. Ali, za razliku od autorâ udžbenika za srednje tehničke i stručne škole, prećutali su Emira Kusturicu, njegove filmove i nagrade sa najprestižnijih međunarodnih festivala. ${ }^{38}$

Bošnjački a ne bosanskohercegovački karakter udžbenikâ historije potvrđuje i dublja analiza sadržaja teksta. U temi o Prvom svjetskom ratu u

\footnotetext{
${ }^{28}$ H. Hadžiabdić i dr., Historija, udžbenik za srednje tehničke i stručne škole, 331; H. Hadžiabdić i dr., Historija/Istorija/Povijest 4, 104.

${ }^{29}$ H. Hadžiabdić i dr., Historija, udžbenik za srednje tehničke i stručne škole, 335; H. Hadžiabdić i dr., Historija/Istorija/Povijest 4, 111.

${ }^{30}$ H. Hadžiabdić i dr., Historija/Istorija/Povijest 4, 88.

${ }^{31}$ Isto, 143; H. Hadžiabdić i dr., Historija, udžbenik za srednje tehničke i stručne škole, 353.

${ }^{32}$ Z. Milutinović, $n$. $d$.

${ }^{33}$ I. Šabotić i M. Čehajić, n. d., 149.

${ }^{34}$ Isto, 177.

${ }^{35}$ Z. Šehić, A. Kovačević i A. Leko, n. d., 141.

${ }^{36}$ Ispred Andrića su Mehmedalija Mak Dizdar, Zija Dizdarević, Rasim Filipović, Skender Kulenović, Husnija Čengić i Antun Branko Šimić. H. Hadžiabdić i dr., Historija, udžbenik za srednje tehničke i stručne škole, 335; H. Hadžiabdić i dr., Historija/Istorija/Povijest 4, 111.

${ }^{37}$ Isto, 376. U gimnazijskom udžbeniku nema prikaza kulture socijalističkog perioda.

${ }^{38}$ Z. Šehić, A. Kovačević i A. Leka, n. d., 231; H. Hadžiabdić i dr., Historija, udžbenik za srednje tehničke i stručne škole, 377.
} 
fokusu svih udžbenika su pripadnici austrougarske vojske iz BiH. U udžbeniku za osnovce karakterišu se kao „hrabri, odlični, požrtvovani i odani borci““ 39

Stvaranje Jugoslavije 1918. godine se ne vrednuje. Na 326. stranici udžbenika za srednje stručne i tehničke škole nalazi se rečenica: „U sastav zajedničke države južnoslovenskih naroda, Kraljevine Srba, Hrvata i Slovenaca ušle su južnoslovenske zemlje: Slovenija, Hrvatska, Bosna i Hercegovina, Srbija (sa Kosovom i Vojvodinom), Crna Gora i Makedonija." Izgleda da su autori pomiješali 1974. ili 1991. sa 1918. godinom.

U prikazu perioda Kraljevine Srba, Hrvata i Slovenaca (SHS)/Jugoslavije u svim analiziranim udžbenicima naglašava se: „teritorijalni

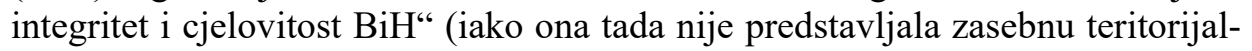
no-političku cjelinu), muslimani kao žrtve agrarne reforme, kritika Sporazuma Cvetković-Maček iz 1939. godine. Viđenje pomenutog Sporazuma isključivo sa muslimanske strane predstavljeno je za svebosanskohercegovačko. On je, po autorima udžbenika za osnovce, bio u ,potpunosti na štetu Bosne i Hercegovine“ i njime je ,dodatno narušena kompaktnost bosanskohercegovačkog stanovništva“, a postignut je ,bez pitanja i pristanka bosanskohercegovačkih naroda“. ${ }^{40}$ Inače, Sporazum su podržale političke stranke koje su na izborima 1938. godine dobile više nego dvotrećinsku podršku Srba i Hrvata u pomenutim zemljama, naroda koji su tada činili blizu dvije trećine njihovog stanovništva.

U prikazu Drugog svjetskog rata fokus svih udžbenika historije je na obnovi državnosti BiH. Stoga su partizani idealizovani. Njihova antifašistička i revolucionarna borba uglavnom je istrgnuta iz jugoslovenskog konteksta i svedena na $\mathrm{BiH}$.

U predstavljanju socijalističkog perioda u prvom planu su BiH, Sarajevo i muslimani/Muslimani. Z. Šehić, A. Kovačević i A. Leka hronološku tabelu ovog perioda u gimnazijskom udžbeniku započinju: „1945. Treće zasjedanje ZAVNOBiH-a u Sarajevu / 1946. Prvi poslijeratni izbori. Ustav NR BiH, gradnja pruge Brčko-Banovići / 1947. Gradnja pruge Šamac-Sarajevo, osnivanje Univerziteta u Sarajevu (... $)^{\text {‘. }} .41$

Rat u BiH 1992-1995. godine u udžbeniku za deveti razred osnovne škole, a posebno u Nastavnom materijalu, sagledava se kao srpska agresija usmjerena prema Muslimanima/Bošnjacima. Izostavljeni su brojni unutrašnji i spoljni aspekti propasti Jugoslavije. Bošnjačko-hrvatski rat u BiH se pominje jedino u udžbeniku, i to bez razmatranja uzroka i karaktera. ${ }^{42}$ Međumuslimanski sukob u Cazinskoj Krajini prećutali su i autori udžbenika i autori Nastavnog materijala. Dio Nastavnog materijala namijenjen učenicima je ilustrovani tekst od preko 40 stranica o stradanju Muslimana/Bošnjaka, prvenstveno u Sarajevu i Srebrenici. ${ }^{43}$

\footnotetext{
${ }^{39}$ I. Šabotić i M. Čehajić, $n . d$., 127.

${ }^{40}$ Isto, 144-146.

${ }^{41}$ Z. Šehić, A. Kovačević i A. Leka, n. d., 221. Inače, Univerzitet u Sarajevu je osnovan 1949. godine.

42 I. Šabotić i M. Čehajić, n. d., 186.

${ }^{43}$ Opširnije u: Д. Д. Васић, „Настава хисторије...“.
} 
Iz svega navedenog proističe zaključak: autori školskih udžbenika savremenu nacionalnu historiju nisu sagledali iz perspektive BiH već iz perspektive vlastite nacije. ${ }^{44}$ Tačnije, iz perspektive nacionalne ideologije i politike koja Bošnjake poistovjećuje sa $\mathrm{BiH}$, pri tom marginalizujući ostale dvije nacije.

\section{Historija ili viktimologija i srbofobija?}

U svim analiziranim bošnjačkim udžbenicima negativno su vrednovani Hrvati Vladko Maček, zbog sporazuma iz 1939. godine sa D. Cvetkovićem, i Ante Pavelić, poglavnik NDH. U udžbenicima za srednju školu nema negativno vrednovanih muslimana/Muslimana/Bošnjaka. Za razliku od njih, u udžbeniku za deveti razred nemaju dobre ocjene član vlade NDH Džafer beg Kulenović i Pavelićev doglavnik Ademaga Mešić. ${ }^{45}$

Autori bošnjačkih udžbenika su uloge „negativaca“ u jugoslovenskoj istorijskoj drami dodijelili većinom Srbima. Za sve njih to su: Aleksandar I Karađorđević, zbog autoritarnog načina vladavine i protivljenja autonomiji $\mathrm{BiH}$; Dragiša Cvetković, zbog pomenute podjele $\mathrm{BiH}$; i Draža Mihailović, kao vođa pokreta kojem se pripisuje genocid nad muslimanima. Z. Šehić, A. Kovačević i A. Leka pišu da je atentat u skupštini Kraljevine SHS 20. juna 1928. „,naručio sam kralj“ Aleksandar I Karađorđević. ${ }^{46} \mathrm{Na}$ neutemeljenost te tvrdnje upućuje i činjenica da se u drugim bošnjačkim udžbenicima ne navodi tako teška diskvalifikacija ličnosti koja je obilježila prvu Jugoslaviju. U srednjoškolskim udžbenicima H. Hadžiabdića i dr. ratni zločinci, pored D. Mihailovića, jesu i Radoslav Radić, Radovan Karadžić i Ratko Mladić. ${ }^{47}$ R. Karadžić i Slobodan Milošević, koji se najviše okrivljuje za ratni rasplet jugoslovenske krize, negativne ličnosti su i u udžbeniku za osnovce. ${ }^{48}$ Negativne uloge imaju i Puniša Račić i Pavle Karađorđević, baš kao i u gimnazijskom udžbeniku Z. Šehića, A. Kovačević i A. Leke. ${ }^{49}$ U posljednjem udžbeniku u lošem svjetlu su predstavljeni i istaknuti članovi Srpskog kulturnog kluba Slobodan Jovanović, Dragiša Vasić i Stevan Moljević. ${ }^{00}$

U bošnjačkim udžbenicima, u cjelini gledano, Austro-Ugarska je u Prvom svjetskom ratu u odnosu na Srbiju pozitivnije prikazana. Prioritet autorâ je učešće vojnika iz BiH u austrougarskoj vojsci, a stradanje stanovništva im je u drugom planu, premda se procjenjuje na osnovu poređenja podataka iz popisa stanovništva 1895, 1910. i 1921. godine, da je u tom ratu BiH izgubila oko

${ }^{44}$ Sličan zaključak se navodi u analizi istraživača iz Sarajeva objavljenoj u: Obrazovanje u BiH..., 129.

${ }^{45}$ Dž. Kulenović, nasljednik M. Spahe na čelu JMO, u istom udžbeniku pozitivno je vrednovan zbog protivljenja Sporazumu Cvetković-Maček i zalaganja za autonomiju BiH. I. Šabotić i M. Čehajić, $n . d ., 145,155$.

${ }^{46}$ Z. Šehić, A. Kovačević i A. Leka, n. d., 132.

${ }^{47}$ H. Hadžiabdić i dr., Historija, udžbenik za srednje tehničke i stručne škole, 350, 353, 374; H. Hadžiabdić i dr., Historija/Istorija/Povijest 4, 137, 149, 174.

${ }^{48}$ I. Šabotić i M. Čehajić, $n$. d., 183-184, 188.

${ }^{49}$ Isto, 139, 144; Z. Šehić, A. Kovačević i A. Leka, n. d., 132, 134-136.

${ }^{50}$ Z. Šehić, A. Kovačević i A. Leka, n. d., 136. 
300.000 stanovnika, najviše Srba. ${ }^{51}$ U udžbenicima H. Hadžiabdića i dr. stradanje Srba se pominje samo u rečenici: „Mnogi Bosanci i Hercegovci su odmah zaključili da je za atentat na Franza Ferdinanda i njegovu suprugu kriva Srbija. Zbog toga su u Sarajevu počele demonstracije u kojima su uništene brojne srpske kuće i dućani“ ${ }^{52}$ Kao i u drugim bošnjačkim udžbenicima, sa izuzetkom pet rečenica u udžbeniku Z. Šehića, A. Kovačević i A. Leke, prećutani su brojni vidovi svojevrsnog rata koji je protiv Srba vodila austrougarska vlast: demonstracije i pogromi izvan Sarajeva, hapšenja i likvidacije bez suđenja, veleizdajnički sudski procesi, odvođenje uglednih Srba u taoce i internaciju, zločini šuckora ${ }^{53}$ prekoredno mobilisanje $u$ radne odrede i vojsku. ${ }^{54}$ Autori udžbenika za deveti razred navode da je austrougarska vlast ,plašeći se izdaje“ preseljavala srpsko stanovništvo sa istoka zemlje i preduzimala „oštre mjere protiv srpskih političkih aktivista zbog sumnje da stoje iza Sarajevskog atentata ili teže pripajanju Bosne i Hercegovine Srbiji“. Na drugoj strani, ,srbijansko-crnogorska vojska“ je, prema istom udžbeniku, protjerala „bošnjačko stanovništvo uz Drinu“, a njihovu imovinu popalila. ${ }^{55}$

Z. Šehić, A. Kovačević i A. Leka opisujući učešće austrougarskih jedinica sastavljenih od vojnika iz BiH na Balkanskom frontu navode: „U borbama u Srbiji kod Bukve 25. novembra 1914. istakao se Gojkomir Glogovac, koji je odlikovan ordenom Marije Terezije i dobio je plemićku titulu - imenovan je prvim bosanskim vitezom vojske, dobivši titulu barona““ ${ }^{56} \mathrm{Za}$ razliku od „,prvog bosanskog viteza“, koji je navodno ubio ili ranio više stotina srpskih vojnika, istaknute ličnosti koje su doprinijele oslobođenju od tuđinske vlasti i jugoslovenskom ujedinjenju 1918. godine nisu ni pomenute. Autori udžbenika za osnovce napominju: „Južni Slaveni u Austro-Ugarskoj monarhiji izražavali su bojazan zbog očitih nastojanja Srbije da dominira u budućoj zajedničkoj državi““. ${ }^{77}$

${ }^{51}$ Ђорђе Пејановић, Становништво Босне и Хериеговине (Београд: Научна књига, 1955), 54.

${ }^{52} \mathrm{H}$. Hadžiabdić i dr., Historija, udžbenik za srednje tehničke i stručne škole, 304; H. Hadžiabdić i dr., Historija/Istorija/Povijest 4, 59.

${ }^{53}$ Šuckori su bili narodni naziv za pripadnike Zaštitnog odreda (Shutzkorps), neredovne jedinice koja je služila kao ispomoć žandarmeriji. Austrougarska vlast u BiH regrutovala je šuckore iz redova odanog rimokatoličkog i muslimanskog stanovništva.

${ }^{54}$ Đorđe Mikić, Austrougarska ratna politika u Bosni i Hercegovini 1914-1918. (Banjaluka: Nezavisni univerzitet Banjaluka, 2011).

${ }^{55}$ I. Šabotić i M. Čehajić, $n$. d., 125, 129.

${ }^{56}$ Z. Šehić, A. Kovačević i A. Leka, $n$. d., 89. „Natporučnik Gojkomir Glogovac je dopuzao sa jednim mitraljezom i trojicom vojnika, koji su uzeli pet redenika municije u jednu zasjedu pred položajem, koji je bio izgubljen. Pustili su da se masa primakne do ruba i tada su otvorili paljbu sa udaljenosti od 100 do 150 koraka, ispaljujući u kratkom periodu 750 patrona (...) Pioniri, koji su narednog dana sahranjivali mrtve, našli su pred položajima (...) oko 400 ranjenih i mrtvih Srba, dok su se ostali povukli sa već osvojenog vrha u dolinu Dragoviljske." Poslije rata kapetan Glogovac vratio se u Hrvatsku i stupio u redove vojske Kraljevstva SHS. Nakon što mu je naređeno da učestvuje u zauzimanju teritorije na granici sa Austrijom dezertirao je u Mađarsku, gdje je ubrzo umro. Zijad Šehić, U smrt za cara i domovinu! Bosanci i Hercegovci u vojnoj organizaciji Habsburške monarhije 1878-1918 (Sarajevo: Sarajevo Publishing, 2007), 132-133.

${ }^{57}$ I. Šabotić i M. Čehajić, n. d., 129. 
Agrarna reforma u Kraljevini SHS, u okviru koje su u BiH konačno ukinuti feudalni odnosi, za I. Šabotića i M. Čehajića je nepravda jer „bošnjački zemljoposjednici bili su potpuno uništeni““. ${ }^{58} \mathrm{U}$ cilju što veće viktimizacije muslimana autori su iznijeli netačan podatak da je do 1941. godine jugoslovenska vlast isplatila manje od $5 \%$ naknade za oduzetu zemlju begovima i agama. ${ }^{59}$ Autorski tim predvođen Z. Šehićem ne bavi se ovom temom. Za razliku od njega, u srednjoškolskim udžbenicima $H$. Hadžiabdić i dr. agrarne nemire i reformu u godinama nakon Prvog svjetskog rata predstavili su kao: bezakonje, pljač$\mathrm{ku}$, paljenje, oduzimanje imovine, iseljavanje u Tursku, ubistva stotine muslimana. Vlast Kraljevine SHS/Jugoslavije prikazali su izrazito nepovoljno, prvenstveno odlomcima iz više knjiga. Na primjer: „Muslimani i katolici tuže se masovno da su po svuda zapostavljeni i progonjeni... Sastav vlade, sva bolja i unosnija mjesta i namještenja sve je to povjereno Srbima kao da drugih i nema...". 60

Najveća stradanja u istoriji na ovim prostorima desila su se u Nezavisnoj Državi Hrvatskoj (NDH), u čije granice su 1941-1945. godine bile uključene i Bosna i Hercegovina. Po udžbeniku I. Šabotića i M. Čehajića ustaše su vršile „masovne progone Srba, Jevreja i Roma“. Autori dodaju u sljedećoj rečenici: „Također su progonjeni mnogi Bošnjaci i Hrvati koji se nisu slagali sa ustaškim terorom ili su bili simpatizeri Komunističke partije." Pominju koncentracione logore $\mathrm{u}$ „Jasenovcu, Gospiću, Staroj Gradišci i drugim mjestima u kojima je stradao veliki broj nevinih ljudi“. Po I. Šabotiću i M. Čehajiću, „Uporedo sa zločinima ustaša nad srpskim življem započeli su i zločini četnika nad Bošnjacima i Hrvatima". 61

Z. Šehić, A. Kovačević i A. Leka tvrde da se desio „,̌etnički genocid nad Muslimanima“, dok su istovremeno u NDH trajali ,progoni srpskog i jevrejskog stanovništva“. O ,progonima“ i ,istrebljenju“, kako ga nazivaju na jednom mjestu, u NDH napisali su osam redova, ${ }^{62}$ dok su partizanskoj borbi isključivo u BiH i ,izgradnji bosanskohercegovačke državnosti“ posvetili devet stranica gimnazijskog udžbenika!? Partizanski pokret predstavljen je bezgrešnim. Na propagandu tog pokreta, rivalskog u borbi za vlast, liči opis četnika u bošnjačkim udžbenicima. Zbog deklarativno jugoslovenskog, a u suštini srpskog obilježja, četnički pokret predstavljen je kao Apsolutno zlo. Njegove tamne strane - pojave kolaboracije i ratnih zločina nad hrvatskim i muslimanskim

\footnotetext{
${ }^{58}$ Isto, 147.

${ }^{59} \mathrm{O}$ različitim stranama agrarne reforme, uključujući i naknadu begovima i agama, vidjeti u: Milivoje Erić, Agrarna reforma u Jugoslaviji 1918-1941 god. (Sarajevo: Veselin Masleša, 1958), 438-452; Milan Gaković, „Rješavanje agrarnog pitanja u Bosni i Hercegovini 19181921“, Prilozi Instituta za istoriju, VI, (1970), 101, 104-105, 109, 110-115; Edin Mutapčić, „Pravno-historijski kontekst agrarne reforme u BiH poslije Prvog svjetskog rata“, Tranzicija/Transition, Časopis za ekonomiju i politiku tranzicije/Journal of economic and politics of Transition, god. XIII, br. 27, (2011). Uporediti sa: Mustafa Imamović, Historija Bošnjaka (Sarajevo: Bošnjačka zajednica kulture Preporod, 1997), 509-510.

${ }^{60}$ Citat u H. Hadžiabdić i dr., Historija/Istorija/Povijest 4, 101-102. iz knjige: Nedim Šarac, Uspostavljanje šestojanuarskog režima sa posebnim osvrtom na BiH (Sarajevo: Svjetlost, 1975).

${ }^{61}$ I. Šabotić i M. Čehajić, n. d., 155.

${ }^{62}$ Z. Šehić, A. Kovačević i A. Leka, n. d., 170.
} 
stanovništvom, preuveličane su i prenaglašene. Prećutana je, sem, donekle, u udžbeniku Z. Šehića, A. Kovačević i A. Leke, podrška četničkom pokretu (do 1944. godine) država Antifašističke koalicije, kralja Petra II i međunarodne priznate vlade Jugoslavije u egzilu, u kojoj je D. Mihailović bio ministar vojni. ${ }^{63}$

U srednjoškolskim udžbenicima Hadžiabdića i dr. stradanje Srba u NDH pominje se samo u dvije rečenice, od kojih prva glasi: „Srbi, Jevreji i Romi našli su se na udaru ustaške vlasti koja ih je htjela istrijebiti“. Potom se opisuje stradanje Jevreja i spašavanje jevrejske knjige Hagada. Slijede pasusi o proganjanju Hrvata „koji se nisu slagali sa politikom NDH“, o protestima muslimana u BiH protiv ustaških zločina ,nad Jevrejima, Srbima i Romima“, te o četničkim ,masovnim pokoljima“. 64

U krcatoj i traumatičnoj istoriji stradanja stanovnika Bosne i Hercegovine u 20. vijeku izdvaja se veličinom i tragikom sudbina srpskog naroda sa Kozare u toku i nakon junske i julske ofanzive 1942. godine njemačkog okupatora i oružanih snaga NDH. Oko 68.000 Kozarčana, uglavnom staraca, žena i djece, dijelom su transportovani na rad u Njemačku, dijelom su raseljeni, a desetine hiljada završili su u sistemu logora Jasenovac i logorima za djecu. Po udžbeniku I. Šabotića i M. Čehajića: „Partizani i narod Kozare uz ogromne napore i velike žrtve uspjeli su probiti neprijateljski obruč i prebaciti se na planinu Grmeč." Ovaj tekst je ilustrovan sa tri fotografije. Opis prve dvije glasi: „Povlačenje stanovništva ispred neprijatelja pod okrilje Kozare i zaštitu partizanske vojske“, a ispod fotografije spomenika na Mrakovici opet se ne pominju Srbi već ,žrtve nacističkog terora“. ${ }^{65} \mathrm{U}$ gimnazijskom udžbeniku Z. Šehića, A. Kovačević i A. Leke žrtve „,neprijatelja“ na Kozari 1942. godine su „partizani“, „civili“ i ,stanovništvo“; dio njih je uspio da se probije iz obruča, a dio njih, za razliku od opisa istog zbivanja u udžbeniku za osnovnu školu, odveden je u logore. ${ }^{66}$ Zatiranje srpskog naroda na Kozari, ustaničkom žarištu, bio je cilj njemačkog okupatora i NDH. Taj cilj je postignut na stranicama udžbenikâ historije - Srba na Kozari nema. U udžbenicima Hadžiabdića i dr. nema ni Kozare, nema ni Jasenovca.

Predstavu u udžbenicima muslimana/Muslimana/Bošnjaka kao žrtava i heroja, kao Apsolutnog dobra, kvari učešće u ustaškom režimu u NDH, te kolaboracija sa njemačkim okupatorom. O tome se uzgredno piše. Jedna glosa bošnjačkog udžbenika za osnovce glasi: „Nastojanje dijela bošnjačkih političara da Bosnu i Hercegovinu izdvoje iz sastava NDH i stave pod njemačku zaštitu Nijemci su iskoristili tako što su formirali 13. SS ili, 'handžar' diviziju. Tu diviziju koja je bila sastavni dio njemačke oružane sile (Wehrmachta) činili su najvećim dijelom Bošnjaci uz manji broj Hrvata." Ko očekuje da slijedi rečenica o

${ }^{63}$ I. Šabotić i M. Čehajić, n. d., 155-156, 159; H. Hadžiabdić i dr., Historija, udžbenik za srednje tehničke i stručne škole, 350, 355; H. Hadžiabdić i dr., Historija/Istorija/Povijest 4, 137, 149; Z. Šehić, A. Kovačević i A. Leka, n. d., 170, 174-176.

${ }^{64} \mathrm{H}$. Hadžiabdić i dr., Historija, udžbenik za srednje tehničke i stručne škole, 349-350; H. Hadžiabdić i dr., Historija/Istorija/Povijest 4, 137.

${ }^{65}$ I. Šabotić i M. Čehajić, n. d., 158-159; Д. Д. Васић, „Настава хисторије...“, 168.

${ }^{66}$ Z. Šehić, A. Kovačević i A. Leka, n. d., 175. 
groznim zločinima koji su ti SS-ovci počinili, a o kojima je pisano u naučnoj literaturi, ${ }^{67}$ vara se. „Upućeni na obuku u Francusku oni su se pobunili u gradu Vilefransu (Villefranch), što je u historiji zabilježeno kao jedini slučaj pobune u njemačkoj vojsci tokom Drugog svjetskog rata." Tu je kraj glose. (U udžbeniku nigdje nisu pojašnjeni nastanak i uloga SS jedinica u Trećem rajhu jer bi to pokvarilo poruku teksta da su „Bošnjaci“ dobri i kada su SS-ovci). ${ }^{68}$

Autori udžbenika za osnovce iznose tezu, bez ikakvog obrazloženja, da je u socijalističkoj Jugoslaviji prije Ustava iz 1974. godine postojala „srpska prevlast" i da je S. Milošević po dolasku na vlast 1987. godine pokušao da istu obnovi. ${ }^{69}$ Po udžbenicima Hadžiabdića i dr. poslije Titove smrti „u srpskim političkim i intelektualnim krugovima otvoreno je traženo (...) ukidanje autonomije Vojvodine i Kosova“" ${ }^{70}$

Rat je 1992. godine po Nastavnom materijalu izbio zbog ,strategije i planova koje su susjedne države Srbija i Hrvatska imale prema Bosni i Hercegovini i koje su provodile uz pomoć svojih pristalica unutar Bosne i Hercegovine. Po mir i državnu egzistenciju najopasniji su bili planovi srbijanskog rukovodstva (...).“ A. Muminović i A. Hasičić pišući o početku rata njegovu eskalaciju posebno vezuju za prekid masovnih mirovnih protesta u Sarajevu 5. aprila 1992. iznoseći nedokazanu tvrdnju: „Srpski snajperisti su pucali na okupljene građane (... $)^{6} .^{71}$ Percepcija druge strane ovog, kao i svih drugih zbivanja nije navedena. $^{72} \mathrm{Na}$ takav i slične načine srpska strana u ratu 1992-1995. godine predstavljena je kao Apsolutno zlo.

Iz teksta bošnjačkog udžbenika za osnovce i Nastavnog materijala proizilazi da su potomci preživjelih kozaračkih Srba iz Drugog svjetskog rata, između ostalih, kao pripadnici Jugoslovenske narodne armije i oružanih snaga Srpske izvršili agresiju na BiH. Za razliku od opisa zločina u Drugom svjetskom ratu, žrtve u Potkozarju su nacionalno identifikovane: „Bošnjaci i Hrvati““. Drastičan primjer preuveličavanja stradanja Muslimana/Bošnjaka (dijelom i Hrvata) i predstavljanja srpske strane u ratu kao Apsolutnog zla, kao i neuvažavanja različitosti dva istorijska konteksta, nalazi se na 28. strani Nastavnog materijala. Tu su uporedo postavljena tri para fotografija: „Davidove zvijezde za označavanje Jevreja“ i „Bijele trake za označavanje Bošnjaka i Hrvata u Prije-

${ }^{67}$ Enver Redžić navodi izvještaj ustaške provenijencije iz aprila 1944. po kome su pripadnici 13. SS divizije u okolini Brčkog i Bijeljine „klali sve što ne nosi fes“. Enver Redžić, Muslimansko autonomaštvo i 13. SS divizija: autonomija Bosne i Hercegovine i Hitlerov Treći Rajh (Sarajevo: Svjetlost, 1987), 172. Najnovija knjiga o toj temi je: Xavier Bougarel, La division Handschar Waffen-SS de Bosnie 1943-1945 (Paris: Passes Composes, 2020).

${ }^{68} \mathrm{Na}$ ovaj dio udžbenika I. Šabotića i M. Čehajića kao primjer predstavljanja istorije samo iz bošnjačke perspektive upozorava i analiza Obrazovanje u BiH..., 129. Autori se u analizi ne bave pseudonaučnošću ovog dijela udžbenika. Vidjeti i: Д. Д. Васић, „Настава хисторије...“, 168.

${ }^{69}$ I. Šabotić i M. Čehajić, $n$. d., 179.

${ }^{70}$ H. Hadžiabdić i dr., Historija, udžbenik za srednje tehničke i stručne škole, 372; H. Hadžiabdić i dr., Historija/Istorija/Povijest 4, 172.

${ }^{71}$ A. Muminović, A. Hasićić i M. Forić Plasto, n. d., 6-7.

$72 \mathrm{O}$ zloupotrebi multiperspektivnog pristupa u predstavljanju zločinâ na pijaci Markale: Д. Д. Васић, „Настава хисторије...“, 169-170. 
doru“, „Koncentracioni logor Buchenwald“ i „Logor za Bošnjake i Hrvate (Trnopolje)“, „Masovne grobnice Majdanek“ i ,Masovne grobnice Pilica (Zvornik)““. 73 Ovakva neumjesna poređenja predstavljaju omalovažavanje milionskih žrtava Holokausta. Inače, nije dokazano korišćenje bijelih traka za označavanje Muslimana i Hrvata u Prijedoru, pogotovo ne u svrhu u koju su koristili nacisti žute trake za Jevreje. Snimak iz logora Trnopolje, objavljen tokom rata i na naslovnici Tajma, u literaturi se koristi kao primjer manipulacije fotografijom kao istorijskim izvorom. ${ }^{74}$

Po pisanju A. Muminović i A. Hasičića njihovi sugrađani u ratnom Sarajevu ,živjeli su bez hrane, vode, struje, plina i ogrjeva“. ${ }^{75}$ Da su isti autori povremeno gubili svaki osjećaj za realnost svjedoči i opis sljedeće scene tokom borbi u istočnoj Bosni 1993. godine. „Desetine hiljada izbjeglica koje su se slile u Srebrenicu čekale su ishod bitke pod otvorenim nebom na srebreničkim ulicama, na koje je neprestano padao veliki broj artiljerijskih i raketnih projektila raznih tipova i kalibara“" 76

Đacima je u Nastavnom materijalu poslata poruka da je Republika Srpska rezultat agresije, zločina i okupacije. Napadnut je Dejtonski mirovni sporazum i ustavno uređenje $\mathrm{BiH}$, jer ,,ratne linije razgraničenja su postale međuentitetske linije, a političko-nacionalna podijeljenost zemlje i društva je potvrđena kao i tekovine etničkog čišćenja“، 77

\section{Zaključak}

$\mathrm{Na}$ osnovu vannaučne istoriografije ili nezavisno od nje u bošnjačkim udžbenicima postoji niz zloupotreba savremene istorije: korišćenje nevjerodostojnih izvora i neutemeljenih podataka iz literature (učešće kralja Aleksandra u skupštinskom atentatu 1928. godine; napad na protivratni protest u Sarajevu aprila 1992; fotografija logoraša iz Trnopolja 1992. godine); preuveličavanje (uloga vojnika iz $\mathrm{BiH}$ u austrougarskoj vojsci; posljedice agrarne reforme $\mathrm{u}$ Kraljevini SHS; reakcije u BiH na Sporazum Cvetković-Maček; žrtve Muslimana/Bošnjaka u ratovima), negiranje, omalovažavanje i zanemarivanje istorijskih činjenica (stradanje u ratovima drugih, naročito Srba; istorijska uloga Ive Andrića; bošnjačko-hrvatski rat 1993-1994. godine); striktno vezivanje za pojedine događaje, pojave i ličnosti uz prikrivanje drugih (partizanski pokret; 13.

\footnotetext{
${ }^{73}$ A. Muminović, A. Hasičić i M. Forić Plasto, n. d., 28.

74 Noam Čomski, Jugoslavija. Mir, rat i raspad, priredio Davor Džalto (Beograd: Samizdat, 2019), 75-76; Sandra Viteljić, Rat slikama - Suvremena ratna fotografija (Zagreb: Algoritam, 2013); Saša Buljević, „Genocid u nastavi - opasnost po pedagoške i obrazovne ciljeve“, https://www.skolegijum.ba/tekst/index/1583/genocid-u-nastavi-opasnosti-po-pedagoske-iobrazovne-ciljeve (pristupljeno 19. 10. 2018); M. Forić Plasto, „Podijeljena prošlost za podijeljenu budućnost!?”, 247-248; Д. Д. Васић, „Настава хисторије... “, 158, 160-161, 174.

75 A. Muminović, A. Hasičić i M. Forić Plasto, n. d., 16, 24; Д. Д. Васић, „Настава хисторије...“", 156.

${ }^{76}$ A. Muminović, A. Hasičić i M. Forić Plasto, n. d., 39; Д. Д. Васић, „Настава хисторије...“, 156.

${ }^{77}$ A. Muminović, A. Hasičić i M. Forić Plasto, n. d., 32; Д. Д. Васић, „Настава хисторије...“, 158.
} 
SS divizija; stradanja u Sarajevu i Srebrenici u ratu 1992-1995. godine); neumjesna poređenja (stradanje Muslimana/Bošnjaka u ratu 1992-1995. godine i Holokaust); kidanje istorijskih zbivanja, pojava i procesa iz njihovih konteksta (istorije muslimana/Muslimana i BiH iz istorije Jugoslavije); upotreba anahronizama (etnonimi Musliman i Bošnjak, administrativna podjela Jugoslavije) itd.

Autori bošnjačkih udžbenika su istoriju svog naroda predstavili kao istoriju čitave Bosne i Hercegovine uz marginalizovanje srpske i hrvatske komponente u procesima, pojavama i zbivanjima. Svoj narod su prikazali kao Apsolutno dobro dodijelivši njegovim pripadnicima uloge heroja i uloge žrtava zločinâ, uključujući i genocide. Pripadnike srpskog naroda predstavili su kao Apsolutno zlo, prvenstveno četnike u Drugom svjetskom ratu i ,velikosrpske agresore“ u građanskom ratu 1992-1995. godine. Prećutali su, prikrili ili omalovažili stradanja Srba u ratovima u 20. vijeku jer ona remete predstavljanje istih kao zlotvora, antiheroja i neprijatelja.

Zajednička patnja i sjećanje na nju, te neprijateljstvo prema susjedima kao vinovnicima te patnje najčvršće grade nacionalno jedinstvo. ${ }^{78} \mathrm{U}$ toj funkciji viktimizacija i srbofobija čine suštinu sadržaja bošnjačkih udžbenika savremene istorije i njihove dopune.

\section{REFERENCE}

- Bagdasaryan, V. È. „Stanovlenie obraza istoričekogo vraga v shkol'nyh uchenikah istorii na postsovetskom prostranstve“. V: Prepodovanie voennoy istorii $v$ Rossii $i$ za rubezhom. Red. K. A. Pahalyuka, 67-86. Moskva, SanktPeterburg: Nestor-Istoriya, 2018.

- Buljević, Saša. „Genocid u nastavi - opasnost po pedagoške i obrazovne ciljeve“. https://www.skolegijum.ba/tekst/index/1583/genocid-u-nastavi-opasnostipo-pedagoske-i-obrazovne-ciljeve (pristupljeno 19. 10. 2018).

- Čomski, Noam. Jugoslavija. Mir, rat i raspad. Priredio Davor Džalto. Beograd: Samizdat, 2019.

- Dedijer, Vladimir. Sarajevski atentat. I-II. Reprint drugog dopunjenog izdanja. Banja Luka: Narodna i univerzitetska biblioteka, 2015.

- Filipović, Emir, Sanja Gladanac, Amila Kasumović, Marija Naletilić, Mirjana Trbojević, i Edin Veladžić. Zloupotreba istorije u procesima koji su doveli do zadnjeg rata u Bosni i Hercegovini: Okvir za promjenu paradigme u izučavanju istorije u BiH školama. Urednik Edin Radušić. Sarajevo: Udruženje nastavnika i profesora historije/istorije/povijesti u Bosni i Hercegovini - EUROCLIO HIP BIH, 2015.

- Forić Plasto, Melisa. „Podijeljena prošlost za podijeljenu budućnost!? Rat 1992-1995. u aktuelnim bosanskohercegovačkim udžbenicima historije“. $R a$ dovi Filozofskog fakulteta u Sarajevu (Historija, Historija umjetnosti, Arheologija), knjiga 6, (2019), 231-257.

\footnotetext{
${ }^{78}$ Eric. J. Hobsbawm, Nacije i nacionalizam. Program, mit, stvarnost (Zagreb: Novi Liber, 1993), 189.
} 
- Hadžiabdić, Hadžija, Edis Dervišagić, Alem Mulić, i Vahidin Mehić. Historija/Istorija/Povijest 4, udžbenik za četvrti razred gimnazije. Tuzla: Bosanska knjiga, 2007.

- Hadžiabdić, Hadžija, Edis Dervišagić, Alem Mulić, i Vahidin Mehić. Historija, udžbenik za srednje tehničke i stručne škole. Tuzla: Bosanska knjiga, 2013.

- Hobsbawm, Eric. J. Nacije i nacionalizam. Program, mit, stvarnost. Zagreb: Novi Liber, 1993.

- Husić, Mensur. „Ideološka dimenzija obrazovanja u Bosni i Hercegovini paradigma koja se obnavlja“. Zbornik radova Pravnog fakulteta u Tuzli, god. III, br. 2, (2017), 162-176.

- Imamović, Mustafa. Historija Bošnjaka. Sarajevo: Bošnjačka zajednica kulture Preporod, 1997.

- Ivić, Ivan, Ana Pešikan, i Slobodanka Antić. Vodič za dobar udžbenik. Opšti standardi kvaliteta udžbenika. Novi Sad: Platoneum, 2010.

- Jozelić, Jasna. "Teaching History with an Ethno-Nacionalistic Approach: History Textbooks in educaton System of Bosnia and Herzegovina". In: Nationhood and Politicization of History in School Textbooks. Identiity, the Curriculum and Educational Media. Edited by Gorana Ognjenović and Jasna Jozelić, 213-225. Palgrave Macmillan, 2020. https://doi.org/10.1007/978-3-030-38121-9_11

- Kargo Haike, i Katarina Batarilo. Reforma nastave historije u Bosni i Hercegovini. Modernizacija udžbenika historije u BiH: od uklanjanja uvredljivog sadržaja iz udžbenika u toku 1999. godine do nove generacije udžbenika u školskoj 2007./2008. godini. Braunschweig: Institut za međunarodno istraživanje udžbenika Georg Eckert, 2008.

- Katz, Vera. „Analiza udžbenika historije u Bosni i Hercegovini (8. i 9. razred osnovne škole, 4. razred gimnazije i 1. i 2. razred stručnih škola)“. U: Udžbenici istorije u post-konfliktnim društvima: Obrazovanje za pomirenje? Urednica Marijana Toma, 52-63. Beograd: Fond za humanitarno pravo, 2015.

- Latinović, Goran. „O muslimanskim udžbenicima istorije“. Zbornik za istoriju Bosne i Hercegovine, 6, (2009), 329-343.

- Mikić, Đorđe. Austrougarska ratna politika u Bosni i Hercegovini 1914-1918. Banjaluka: Nezavisni univerzitet Banjaluka, 2011.

- Milutinović, Zoran. Bitka za prošlost. Ivo Andrić i bošnjački nacionalizam. Beograd: Geopoetika izdavaštvo, 2018.

- Muminović, Azerina, Asmir Hasičić, i Melisa Forić Plasto. Nastavni materijal za izučavanje opsade Sarajeva i zločina genocida počinjenog u Bosni i Hercegovini u periodu od 1992. do 1995. godine u osnovnim i srednjim školama Kantona Sarajevo. Sarajevo: Ministarstvo za obrazovanje, nauku i mlade Kantona Sarajevo, 2018.

- Obrazovanje u BiH: čemu (ne) učimo djecu? Analiza sadržaja nacionalne grupe predmeta u osnovnim školama. Sarajevo: Mas Media Sarajevo, Fond otvoreno društvo $\mathrm{BiH}, 2017$.

- Osveshchenie obshchej istorii Rossii i narodov postsovetskih stran v shkol'nyh uchebnikah istorii novyh nezavisimyh gosudarstv, red. A. A. Danilov i A. I. 
Vdovin. Moskva: Gosudarstvenyj klub, Nacional'naya laboratoriya vneshnej politiki, 2009.

- Pejanović, Đorđe. Stanovništvo Bosne i Hercegovine. Beograd: Naučna knjiga, 1955.

- Pingel, Falk. UNESCO. Vodič za istraživanje i reviziju udžbenika. Zagreb: Profil, 2000.

- Pingel, Falk. "A Clash of Communication? Intervening in Textbook Writing and Curriculum Development in Bosnia and Herzegovina after the War 19921995". In: History Education and Conflict Transformation. Social Psychological Theries, History Teaching and Reconciliation. Editors Charis Psaltis, Mario Carretero and Sabina Čehajić-Clancy, 231-254. Palgrave Macmillan, 2017. https://doi.org/10.1007/978-3-319-54681-0_9

- „Ratovi u udžbenicima. Analiza sadržaja o ratovima 90-ih u udžbenicima historije u Bosni i Hercegovini, Hrvatskoj i Srbiji“. Pripremila Melisa Forić Plasto. http://cliohipbih.ba/wp-content/uploads/2018/12/Ratovi-u-udžbenicima.pdf (pristupljeno 20. 11. 2019).

- Redžić, Enver. Muslimansko autonomaštvo i 13. SS divizija: autonomija Bosne i Hercegovine i Hitlerov Treći Rajh. Sarajevo: Svjetlost, 1987.

- Slavković Mirić, Božica. „Srpsko-albanski odnosi u albanskom udžbeniku za osmi razred osnovne škole“. Tokovi istorije, br. 1, (2020), 199-220. https://doi.org/10.31212/tokovi.2020.1.sla.199-220

- Stamatović, Aleksandar. Antisrpstvo u udžbenicima istorije u Crnoj Gori. Podgorica: Srpsko narodno vijeće, 2007.

- Šabotić Izet, i Mirza Čehajić. Historija. Udžbenik za deveti razred devetogodišnje osnovne škole. Tuzla: NAM, Zenica: Vrijeme, 2012.

- Šehić, Zijad. U smrt za cara i domovinu! Bosanci i Hercegovci u vojnoj organizaciji Habsburške monarhije 1878-1918. Sarajevo: Sarajevo Publishing, 2007.

- Šehić Zijad, Aida Kovačević, i Alma Leka. Historija, istorija, povijest: udžbenik sa čitankom za četvrti razred gimnazije. Sarajevo: Sarajevo Publishing, 2007.

- Švigir, Domagoj. „Slika, drugoga': predodžbe o Srbina u hrvatskim udžbenicima povijesti za osnovnu školu od 1990. do 2012. godine“. Historijski zbornik, god. LXXI, br. 1, (2018), 105-134.

- Vasić, Dragiša D. „Naučna zasnovanost nastave istorije u osnovnim i srednjim školama u Republici Srpskoj“. U: Nastava istorije u Republici Srpskoj - stanje i perspektive. Urednik Drago Branković, 15-36. Banja Luka: Akademija nauka i umjetnosti Republike Srpske, 2019.

- Vasić, Dragiša D. „Nastava historije ili nastava viktimologije i srbofobije? O izučavanju rata 1992-1995. godine u školama Kantona Sarajevo“. Srpski istorijski časopis, II, (2020), 141-178.

- Vasić, Dragiša D. „Istorija i nacionalni identitet u sarajevskoj magli: primjeri politizacije i mitologizacije bošnjačkog istorijskog narativa“, Tokovi istorije, br. 2, (2020), 209-232. https://doi.org/10.31212/tokovi.2020.2.vas.209-232 
DRAGIŠA D. VASIĆ, PhD, Associate Professor

Faculty of Philosophy, University of Banja Luka

Banja Luka, Republic of Srpska, Bosnia and Herzegovina

dragisa.vasic@ff.unibl.org

CONTEMPORARY NATIONAL HISTORY IN BOSNIAK PRIMARY AND SECONDARY SCHOOL TEXTBOOKS

\section{Summary}

An analysis of the contents of contemporary national history in official primary and secondary school textbooks and their supplements within the Bosniak educational system in Bosnia-Herzegovina reveals their prime motive: their own people as the victim of primarily Serb aggression and atrocities. Guided by this motive, the authors of the textbooks flagrantly violated the principle of the scientific basis of teaching history. The textbooks contain a number of examples showing history being abused: the use of unreliable sources and pseudo-scientific literature, exaggeration, disparagement, denial and neglect of historical facts, strict adherence to certain events, phenomena, or persons while concealing others, inappropriate comparisons, unfounded claims, and taking historical events, phenomena and processes out of context. Collective suffering and the memory of that suffering, as well as hostility toward neighbors as perpetrators of crimes, are the strongest building blocks of ethnic unity. For this purpose, victimology and Anti-Serb sentiments (Serbophobia) are the essence of Bosniak textbooks on contemporary history and their supplements.

KEYWORDS: Bosnia-Herzegovina, Bosniaks, Textbooks, Victimology, Serbophobia, Pseudohistory 